\title{
Pengembangan Ensiklopedia Alat Ukur Fisika sebagai Sumber Belajar untuk Siswa SMP/MTs
}

\author{
I. Maulina*, H. H. Kusuma, dan M. I. Faqih \\ Program Studi Pendidikan Fisika, Fakultas Sains dan Teknologi, UIN Walisongo \\ Semarang, Indonesia \\ *Email:maulin.naaa@gmail.com
}

Received: July 29th 2020 . Accepted: February $4^{\text {th }}$, 2021. Published: February 28 $8^{\text {th }}, 2021$

\begin{abstract}
Abstrak
Penelitian ini bertujuan untuk menghasilkan dan menguji kualitas produk berupa ensiklopedia alat ukur fisika untuk dijadikan sumber belajar bagi siswa SMP/MTs. Jenis penelitian yang digunakan adalah Research and Development (R\&D), mengacu pada pengembangan Borg \& Gall yang telah dimodifikasi oleh Sugiyono. Subjek pada penelitian ini adalah siswa kelas VII SMP Negeri 1 Brangsong. Teknik pengumpulan data pada penelitian ini adalah dengan menggunakan wawancara dan angket. Hasil penilaian kualitas ensiklopedia berdasarkan penilaian dari ahli materi sebesar $100 \%$ dengan kategori sangat baik (sb), ahli media sebesar 94,29\% dengan kategori sangat baik (sb), penilaian dari guru IPA sebesar 93,33\% dengan kategori sangat baik (sb), dan penilaian respons siswa pada uji coba skala kecil sebesar 97,78\% dengan kategori sangat baik (sb). Berdasarkan hasil penilaian ini, dapat ditarik kesimpulan bahwa ensiklopedia alat ukur fisika yang dihasilkan memiliki kualitas sangat baik (sb) dan layak digunakan sebagai sumber belajar untuk siswa SMP/MTs.
\end{abstract}

\begin{abstract}
This research aims to produce a product in the form of an encyclopedia of physics measuring instruments and to find out the quality of the encyclopedia of physics measuring instruments as a learning resource for SMP / MTs students. The type of research used in this research is Research and Development (R\&D), referring to the development of Borg \& Gall which has been modified by Sugiyono. The subjects of this study were students of class VII SMP Negeri 1 Brangsong. Data
\end{abstract}


collection techniques in this study were carried out by means of interviews and questionnaires. The results of the encyclopedia quality assessment based on the evaluation of material experts are $100 \%$ with very good category, media experts are $94.29 \%$ with very good category, assessment from science teachers is $93.33 \%$ with very good category, and the assessment of student responses in the small-scale trial was $97.78 \%$ with the very good category. Based on this assessment, it can be concluded that the encyclopedia of physics measuring instruments developed has very good quality and is suitable for use as a learning resource for SMP / MTs students. C2021PERJ

Keywords: Encyclopedia; Learning Resource; Physics Measuring Instrument.

\section{PENDAHULUAN}

Ilmu Pengetahuan Alam (IPA) adalah suatu cabang ilmu yang mempelajari fenomena alam berupa fakta, konsep dan hukum melalui serangkaian kegiatan metode ilmiah (Fitriyani, 2017). Pengalaman langsung melalui pembelajaran IPA dapat memberikan pemahaman tentang alam sekitar secara ilmiah serta memberikan kesempatan kepada siswa untuk bereksplorasi (Prasetyowati, 2014). Proses pembelajaran IPA pada kurikulum 2013 mengaplikasikan pendekatan ilmiah, yang menuntut siswa untuk aktif, berfikir kritis, dan memiliki keterampilan, sikap, serta pengetahuan melalui proses ilmiah (Ula, et al, 2018). Satu cara yang dapat digunakan untuk melatih penalaran ilmiah siswa adalah melalui pembelajaran berbasis eksperimen yang dilakukan di laboratorium (Varma, 2014).
Laboratorium merupakan sebuah sarana yang bisa digunakan untuk menjadi sumber belajar. Laboratorium sangat diperlukan sebagai tempat pembelajaran sehingga siswa dapat meningkatkan pengetahuan melalui kegiatan praktikum (Kurniawati, 2018). Pengetahuan tentang alat ukur fisika sangat penting dalam mendukung kegiatan praktikum di laboratorium karena penggunaan alat ukur fisika secara kurang tepat berdampak pada kesalahan penggunaan alat dan hasil pengukurannya (Sulistiyawati \& Hedianti, 2015).

Kesalahan yang ditemui dalam penggunaan alat ukur fisika antara lain adalah kesalahan penggunaan satuan, kesalahan dalam meletakkan dan memegang alat ukur, serta kesalahan yang ditimbulkan akibat alat belum dikalibrasi (Sari \& Saputri, 2016). Kesalahan dalam penggunaan alat 
ukur perlu disikapi sebab dapat menimbulkan dampak pada hasil belajar siswa (Nasution, 2019). Salah satu upaya untuk mengurangi kesalahan dalam penggunaan alat ukur adalah dengan melakukan pelatihan penggunaan alat ukur bagi guru-guru IPA (Rohmawati, dkk., 2015).

Menurut Peraturan Menteri Pendidikan Nasional Nomor 24 Tahun 2007, yaitu tentang Standar Sarana dan Prasarana Sekolah, alat ukur dasar yang harus dimiliki oleh laboratorium sekolah meliputi mistar, rollmeter, mikrometer, jangka sorong, stopwatch, termometer, neraca, dinamometer, gelas ukur, dan multimeter AC/DC. Laboratorium fisika memiliki alat ukur yang beragam, dengan berbagai fungsi dan cara penggunaan yang berbeda. Oleh sebab itu, siswa dituntut untuk memiliki pengetahuan tentang alat ukur fisika yang meliputi nama alat, fungsi, dan cara penggunaannya untuk meminimalisir kesalahan.

Berdasarkan wawancara dengan salah satu guru IPA di SMP Negeri 1 Brangsong Kendal, diketahui bahwa guru IPA hanya mengadakan praktikum di laboratorium untuk materi pelajaran yang dianggap penting oleh guru serta mudah untuk dilaksanakan; misalnya pengukuran panjang, getaran, dan pengukuran arus listrik. Guru memperkenalkan alat ukur fisika kepada siswa sesaat sebelum praktikum dimulai. Akan tetapi karena waktu terbatas, hanya sebagian kecil alat ukur fisika yang diperkenalkan dari keseluruhan alat yang terdapat di laboratorium fisika.

Berdasarkan hasil angket pra penelitian pada siswa kelas VII SMP Negeri 1 Brangsong Kendal, diketahui bahwa pengetahuan siswa tentang alat-alat ukur fisika masih sangat rendah, yaitu $40 \%$ siswa dapat menyebutkan fungsi dan cara penggunaan alat ukur fisika dengan benar dan $60 \%$ siswa tidak dapat menyebutkan secara benar. Fakta ini menunjukkan bahwa 60\% siswa masih kurang memiliki pengetahuan tentang alatalat ukur fisika. Oleh karena itu, diperlukan suatu sumber belajar yang menarik serta mudah dipahami dalam upaya peningkatan pemahaman dan pengetahuan mengenai alat ukur fisika.

Sumber belajar merupakan segala sesuatu yang bisa dimanfaatkan untuk menarik minat dan motivasi siswa terhadap materi pembelajaran yang diberikan (Dwiyogo, 2016). Sumber belajar digunakan untuk membantu siswa mencari pengalaman belajar secara mandiri. Menurut Busljeta (2013), tujuan dan peran sumber belajar tidak hanya membuat proses pembelajaran lebih menarik tetapi mendorong pembelajaran aktif, pengembangan keterampilan, dan penerapan nilai serta sikap yang diinginkan oleh siswa.

Salah satu sumber belajar alternatif yang berisi informasiinformasi terbaru dan akurat adalah 
ensiklopedia (Driscoll, et al, 1994; Sulistiyawati \& Hedianti, 2015). Ensiklopedia adalah salah satu jenis buku yang berisi uraian maupun keterangan mengenai berbagai macam hal dalam bidang ilmu pengetahuan dan seni yang disusun berdasarkan abjad ilmu (KBBI, 2008).

Kelebihan yang dimiliki ensiklopedia sebagai sumber belajar adalah mudah dipahami serta memberikan penjelasan secara lengkap mengenai suatu informasi (Setiadi \& Setiawati, 2016). Penggunaan ensiklopedia dapat menumbuhkan minat dan motivasi untuk mempelajari materi karena pembaca mendapatkan informasiinformasi baru (Devy, 2015). Ensiklopedia memberikan visualisasi yang dapat menarik minat siswa dalam proses pembelajaran (Irawati, 2015). Ensiklopedia juga dapat dijadikan sebagai sumber belajar alternatif karena memuat informasi yang akurat dan terbaru serta memberikan wawasan yang luas bagi para pembacanya (Vannesa, 2013).

Berdasarkan uraian tersebut, mempelajari alat ukur fisika melalui ensiklopedia dapat dijadikan alternatif untuk meningkatkan pengetahuan dan minat baca siswa. Ensiklopedia juga dapat digunakan sebagai sumber belajar bagi siswa. Hal ini menjadi alasan perlunya penelitian ini untuk dilakukan. Tujuan penelitian ini yaitu untuk menghasilkan sebuah produk berupa ensiklopedia alat ukur fisika dan menguji kualitas produk tersebut sehingga dapat dimanfaatkan sebagai sumber belajar siswa SMP/MTs.

Penelitian berupa pengembangan ensiklopedia sains telah dilakukan oleh beberapa pihak lain sebelumnya, misalnya pengembangan ensiklopedia IPA untuk SD/MI (Noviar, 2015), pengembangan ensiklopedi elektronika berbasis wiki (Ansharullah, dkk., 2015), pengembangan ensiklopedia digital berbasis CTL (Nurhatmi, dkk., 2015), pengembangan ensiklopedia peralatan laboratorium biologi di SMP/MTs (Supriyadi \& Lismawati, 2018), dan pengembangan ensiklopedia alat ukur fisika sebagai bahan belajar siswa SMA/MA kelas X (Widiana \& Hasanah, 2014). Hal yang membedakan penelitian sebelumnya dengan ensiklopedia yang dikembangkan dalam penelitian ini yaitu sasaran atau penggunanya. Ensiklopedia yang dihasilkan dari penelitian ini lebih ditujukan untuk siswa SMP/MTs dalam hal alat ukur fisika.

\section{METODE}

Metode yang digunakan adalah penelitian dan pengembangan (Research and Development). Model pengembangan yang diterapkan mengikuti model pengembangan prosedural Borg \& Gall dengan modifikasi dari Sugiyono. Tahap pengembangan yang dilakukan 
meliputi: studi pendahuluan, perencanaan produk, pengembangan produk, validasi produk, revisi produk, dan uji lapangan.

Siswa kelas VII SMP Negeri 1 Brangsong Kendal menjadi subjek pada penelitian ini. Pengambilan sampel dilakukan dengan teknik purposive sampling, yaitu sebuah teknik penentuan sampel menggunakan pertimbangan tertentu (Hatibe, 2012). Teknik pengumpulan data dilakukan melalui wawancara dan penyebaran angket.

Data yang diperoleh dari angket validasi dan uji lapangan kemudian dihitung untuk mengetahui persentase kualitas ensiklopedia menggunakan Persamaan 1 (Akbar, 2013). Kriteria kualitas ensiklopedia alat ukur fisika disajikan pada Tabel 1 (Akbar, 2013).

Persentase $(P)=\frac{\text { Skor Total }}{\text { Skor Maksimal }} \times 100 \%$

Tabel 1. Kriteria Kualitas Ensiklopedia

\begin{tabular}{cc}
\hline Persentase $(\%)$ & Kategori \\
\hline $81 \leq \mathrm{P} \leq 100$ & Sangat Baik \\
$61 \leq \mathrm{P} \leq 80$ & Baik \\
$41 \leq \mathrm{P} \leq 60$ & Cukup Baik \\
$21 \leq \mathrm{P} \leq 40$ & Kurang Baik \\
$0 \leq \mathrm{P} \leq 20$ & Tidak Baik \\
\hline Deskripsi dari & tahapan dalam \\
pengembangan penelitian ini \\
sebagai berikut:
\end{tabular}

\section{Studi Pendahuluan}

Tahapan yang pertama ini bertujuan untuk mengidentifikasi potensi dan masalah. Studi pendahuluan dilakukan dengan melakukan wawancara dan menyebarkan angket pra riset pada siswa. Wawancara dilakukan kepada salah satu guru mata pelajaran IPA, dan angket diberikan pada siswa kelas VII SMP Negeri 1 Brangsong Kendal.

\section{Pengumpulan Data}

Tahap pengumpulan data dilakukan dalam bentuk pengumpulan referensi materi yang berhubungan dengan materi alatalat ukur fisika, meliputi alat ukur panjang, massa, waktu, suhu, kuat arus listrik, intensitas cahaya, dan alat ukur lainnya. Selain itu juga dilakukan pengumpulan ilustrasi berupa gambar yang disesuaikan dengan materi. Perangkat lunak yang digunakan adalah CorelDraw 2018 dan Microsoft Word 2013. CorelDraw 2018 digunakan untuk mendesain halaman cover yaitu cover depan dan cover belakang serta desain bagian tepi setiap halaman pada ensiklopedia. Microsoft word 2013 digunakan untuk mengedit bagian isi ensiklopedia.

\section{Desain Produk}

Desain produk dimulai dengan membuat rancangan awal ensiklopedia yang meliputi cover depan dan cover belakang, nama redaksi, kata pengantar, daftar isi, pembuka bab, isi atau materi yang meliputi: alat ukur panjang, massa, waktu, suhu, kuat arus listrik, 
intensitas cahaya, dan alat ukur lainnya, serta daftar pustaka, indeks, dan glosarium. Tujuan dari rancangan awal adalah untuk mengetahui konsep desain produk yang dikembangkan.

\section{Validasi Produk}

Validasi ensiklopedia dilakukan oleh validator, terdiri atas satu ahli materi, satu ahli media, dan dua guru pengampu mata pelajaran IPA tingkat SMP/MTs. Validasi ahli materi dan media dilakukan oleh dosen pendidikan fisika UIN Walisongo. Penilaian ensiklopedia meliputi kelayakan isi/materi, kebahasaan, dan desain ensiklopedia.

\section{Uji Lapangan}

Uji lapangan dilaksanakan dengan tujuan untuk mengetahui respons siswa terkait kualitas ensiklopedia alat ukur fisika sebagai sumber belajar. Uji lapangan dilakukan kepada 12 siswa kelas VII I SMP Negeri 1 Brangsong Kendal.

\section{HASIL DAN PEMBAHASAN}

Produk yang dihasilkan dari penelitian ini berupa ensiklopedia alat ukur fisika. Cover ensiklopedia ditampilkan pada Gambar 1. Cover didesain dengan menyertakan gambar-gambar alat ukur yang mengilustrasikan isi.
Ensiklopedia ini dicetak dalam kertas berukuran A5.

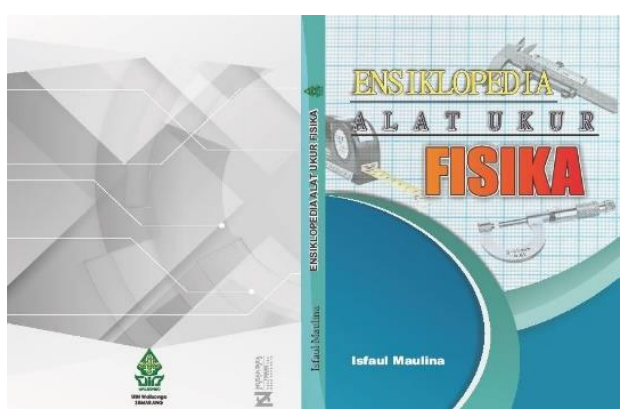

Gambar 1. Cover Ensiklopedia Alat Ukur Fisiks

Data hasil penilaian ensiklopedia yang diberikan oleh ahli materi diperlihatkan pada Tabel 2 . Berdasarkan Tabel 2, hasil penilaian ensiklopedia oleh ahli materi menunjukkan bahwa ensiklopedia alat ukur fisika yang dikembangkan layak untuk digunakan sebagai sumber belajar. Hal ini menunjukkan bahwa isi atau materi yang terdapat dalam ensiklopedia mampu memberikan ilmu pengetahuan baru, meningkatkan pemahaman siswa, menumbuhkan rasa ingin tahu bagi siswa, memberikan informasi yang jelas karena menggunakan bahasa yang efektif dan efisien, serta tata letak materi yang disajikan dapat memudahkan siswa untuk memahami materi. Kritik dan saran perbaikan dari ahli materi yaitu terdapat bebarapa kalimat kurang lengkap namun masih dalam tahap wajar dan sangat bisa dimaklumi. 
Tabel 2. Data Hasil Penilaian Ensiklopedia oleh Ahli Materi

\begin{tabular}{|c|c|c|c|c|c|c|}
\hline $\begin{array}{c}\text { Aspek } \\
\text { Penilaian }\end{array}$ & Indikator & Validator & $\begin{array}{l}\text { Skor } \\
\text { Total }\end{array}$ & $\begin{array}{l}\text { Rata- } \\
\text { rata }\end{array}$ & $\begin{array}{c}\text { Persen } \\
\text { tase } \\
(\%)\end{array}$ & Kriteria \\
\hline \multirow{3}{*}{$\begin{array}{l}\text { Kelayakan } \\
\text { Isi }\end{array}$} & 1 & 5 & 5 & \multirow{3}{*}{5} & \multirow{3}{*}{100} & \multirow{3}{*}{ Sangat Baik } \\
\hline & 2 & 5 & 5 & & & \\
\hline & 3 & 5 & 5 & & & \\
\hline \multirow{3}{*}{ Kebahasaan } & 4 & 5 & 5 & \multirow{3}{*}{5} & \multirow{3}{*}{100} & \multirow{3}{*}{ Sangat Baik } \\
\hline & 5 & 5 & 5 & & & \\
\hline & 6 & 5 & 5 & & & \\
\hline \multirow{4}{*}{$\begin{array}{l}\text { Desain } \\
\text { Media }\end{array}$} & 7 & 5 & 5 & \multirow{4}{*}{5} & \multirow{4}{*}{100} & \multirow{4}{*}{ Sangat Baik } \\
\hline & 8 & 5 & 5 & & & \\
\hline & 9 & 5 & 5 & & & \\
\hline & 10 & 5 & 5 & & & \\
\hline \multicolumn{2}{|c|}{ Jumlah seluruh skor } & 50 & 50 & 5 & 100 & Sangat Baik \\
\hline
\end{tabular}

Penilaian ensiklopedia oleh ahli media didasarkan pada aspek desain media, meliputi: keterbacaan tulisan, kelayakan kegrafikan, warna, kemenarikan cover, layout, ilustrasi atau gambar, dan kualitas buku. Data hasil penilaian ensikopedia oleh ahli media ditampilkan pada Tabel 3.

Tabel 3. Data Hasil Penilaian Ensiklopedia oleh Ahli Media.

\begin{tabular}{|c|c|c|c|c|c|c|}
\hline $\begin{array}{c}\text { Aspek } \\
\text { Penilaian }\end{array}$ & Indikator & Validator & $\begin{array}{l}\text { Skor } \\
\text { Total }\end{array}$ & $\begin{array}{l}\text { Rata- } \\
\text { rata }\end{array}$ & $\begin{array}{c}\text { Persen } \\
\text { tase } \\
(\%)\end{array}$ & Kriteria \\
\hline \multirow{7}{*}{$\begin{array}{l}\text { Desain } \\
\text { Media }\end{array}$} & 1 & 5 & 5 & \multirow{7}{*}{33} & \multirow{7}{*}{94,28} & \multirow{7}{*}{ Sangat Baik } \\
\hline & 2 & 5 & 5 & & & \\
\hline & 3 & 5 & 5 & & & \\
\hline & 4 & 4 & 4 & & & \\
\hline & 5 & 5 & 5 & & & \\
\hline & 6 & 4 & 4 & & & \\
\hline & 7 & 5 & 5 & & & \\
\hline \multicolumn{2}{|c|}{ Jumlah seluruh skor } & 33 & 33 & 4,71 & 94,28 & Sangat Baik \\
\hline
\end{tabular}

Berdasarkan Tabel 3, hasil penilaian ensiklopedia oleh ahli media menunjukkan tingkat kelayakan yang sangat baik. Hal ini menunjukkan bahwa ensiklopedia alat ukur fisika memiliki bahasa dan gambar yang seimbang (dari aspek ukuran maupun pesan yang disampaikan), penempatan ilustrasi atau gambar pada setiap halaman tidak mengganggu kejelasan informasi yang terdapat pada ensiklopedia, kualitas gambar jelas, keterangan ilustrasi gambar jelas dan sesuai, tata letak teks dan gambar proporsional, serta memiliki 
desain cover yang menarik. Cover dengan desain yang menarik merupakan suatu faktor penting karena dapat menimbulkan daya tarik awal sehingga siswa menjadi terdorong untuk membaca ensiklopedia. Kritik dan saran perbaikan dari ahli media antara lain: masih terdapat salah ketik, kurang konsisten dalam hal alinea, penggunaan italic pada kata asing masih belum tepat, masih ditemukan kesalahan pada penulisan tanda baca titik, alignment keterangan gambar masih perlu dirapikan, dan terdapat gambar yang digunakan kurang HD (High Definition).

Tabel 4. Data Hasil Penilaian Ensiklopedia oleh Guru IPA.

\begin{tabular}{|c|c|c|c|c|c|c|c|}
\hline \multirow{2}{*}{$\begin{array}{c}\text { Aspek } \\
\text { Penilaian }\end{array}$} & \multirow{2}{*}{ Indikator } & \multicolumn{2}{|c|}{ Validator } & \multirow{2}{*}{$\begin{array}{l}\text { Skor } \\
\text { Total } \\
\end{array}$} & \multirow{2}{*}{$\begin{array}{l}\text { Rata- } \\
\text { rata }\end{array}$} & \multirow{2}{*}{$(\%)$} & \multirow{2}{*}{ Kriteria } \\
\hline & & $\mathrm{I}$ & II & & & & \\
\hline \multirow{3}{*}{$\begin{array}{l}\text { Kelayakan } \\
\text { Isi }\end{array}$} & 1 & 5 & 4 & 9 & \multirow{3}{*}{4,83} & \multirow{3}{*}{96,67} & \multirow{3}{*}{ Sangat Baik } \\
\hline & 2 & 5 & 5 & 10 & & & \\
\hline & 3 & 5 & 5 & 10 & & & \\
\hline \multirow{4}{*}{ Kebahasaan } & 4 & 4 & 5 & 9 & \multirow{4}{*}{4,67} & \multirow{4}{*}{93,33} & \multirow{4}{*}{ Sangat Baik } \\
\hline & 5 & 5 & 5 & 10 & & & \\
\hline & 6 & 5 & 4 & 9 & & & \\
\hline & 7 & 5 & 4 & 9 & & & \\
\hline \multirow{5}{*}{$\begin{array}{l}\text { Desain } \\
\text { Media }\end{array}$} & 8 & 5 & 5 & 10 & \multirow{5}{*}{4,58} & \multirow{5}{*}{91,67} & \multirow{5}{*}{ Sangat Baik } \\
\hline & 9 & 4 & 5 & 9 & & & \\
\hline & 10 & 5 & 4 & 9 & & & \\
\hline & 11 & 4 & 5 & 9 & & & \\
\hline & 12 & 5 & 4 & 9 & & & \\
\hline \multicolumn{2}{|c|}{ Jumlah seluruh skor } & 57 & 55 & 112 & 14,08 & 93,33 & Sangat Baik \\
\hline
\end{tabular}

Ensiklopedia juga dinilai oleh dua guru IPA SMP Negeri 1 Brangsong. Data hasil penilaian guru diperlihatkan pada Tabel 4 . Berdasarkan Tabel 4, hasil penilaian ensiklopedia oleh dua guru IPA menyatakan bahwa kelayakan ensiklopedia termasuk dalam kategori sangat baik. Hal ini menunjukkan bahwa ensiklopedia alat ukur fisika dapat digunakan sebagai sumber belajar siswa karena memberikan informasi yang jelas dan mudah dipahami, materi yang disajikan dapat memberikan pengetahuan yang baru bagi siswa, bahasa yang digunakan efektif dan efisien, ilustrasi atau gambar yang digunakan mampu menarik minat dan motivasi belajar siswa, perpaduan warna pada cover dan isi ensiklopedia cukup konsisten dan tidak mengganggu keterbacaan tulisan, kualitas gambar jelas, cover ensiklopedia didesain secara menarik dan sesuai dengan materi yang disajikan.

Kritik dan saran perbaikan dari guru IPA yaitu skala pada gambar agar lebih diperbesar lagi, contoh 
atau cara membaca alat ditampilkan lebih sempurna, dan ditambahkan juga biografi penulis.

Hasil uji lapangan ditampilkan pada Tabel 5. Hasil uji lapangan menunjukkan siswa memiliki respons positif terhadap ensiklopedia yang dikembangkan. Ensiklopedia alat ukur fisika memiliki materi yang mudah dipahami siswa sebab berkaitan dengan kehidupan sehari-hari, kalimat yang digunakan sederhana dan tidak sulit dipahami, gambar yang disajikan jelas atau tidak buram, penempatan gambar tidak mengganggu dalam membaca teks atau tulisan, serta tampilan buku sangat bagus dan menarik.

Tabel 5. Hasil Uji Lapangan.

\begin{tabular}{|c|c|c|c|c|c|}
\hline \multirow[t]{2}{*}{ Aspek Penilaian } & \multirow{2}{*}{$\begin{array}{c}\text { Jumlah } \\
\text { Responden }\end{array}$} & \multicolumn{2}{|c|}{ Jawaban } & \multicolumn{2}{|c|}{ Persentase $(\%)$} \\
\hline & & $\mathrm{Ya}$ & Tidak & $\mathrm{Ya}$ & Tidak \\
\hline \multirow{3}{*}{ Materi } & 12 & 12 & 0 & 100 & 0 \\
\hline & 12 & 12 & 0 & 100 & 0 \\
\hline & 12 & 11 & 1 & 91,6 & 8,4 \\
\hline \multirow{7}{*}{ Tampilan } & 12 & 12 & 0 & 100 & 0 \\
\hline & 12 & 12 & 0 & 100 & 0 \\
\hline & 12 & 10 & 2 & 83,3 & 16,7 \\
\hline & 12 & 12 & 0 & 100 & 0 \\
\hline & 12 & 12 & 0 & 100 & 0 \\
\hline & 12 & 12 & 0 & 100 & 0 \\
\hline & 12 & 12 & 0 & 100 & 0 \\
\hline \multirow{5}{*}{ Bahasa } & 12 & 12 & 0 & 100 & 0 \\
\hline & 12 & 11 & 1 & 91,6 & 8,4 \\
\hline & 12 & 12 & 0 & 100 & 0 \\
\hline & 12 & 12 & 0 & 100 & 0 \\
\hline & 12 & 12 & 0 & 100 & 0 \\
\hline \multirow[t]{2}{*}{ Jumlah skor } & & 176 & 4 & & \\
\hline & htase Keseluruhan & & & 97,78 & 2,22 \\
\hline
\end{tabular}

\section{KESIMPULAN}

Berdasarkan hasil penelitian, dapat disimpulkan bahwa kualitas ensiklopedia alat ukur fisika menurut ahli materi mendapatkan penilaian sebesar $100 \%$, ahli media sebesar $94,29 \%$, penilaian dari guru IPA sebesar 93,33\% dan penilaian respons siswa pada uji lapangan sebesar 97,78\%. Hasil penilaian tersebut menunjukkan bahwa ensiklopedia yang dihasilkan memiliki tampilan menarik serta memberikan kemudahan untuk digunakan sebagai sumber belajar. Secara keseluruhan, ensiklopedia yang dikembangkan telah memenuhi kriteria sangat baik pada aspek materi, tampilan, dan bahasa 
sehingga ensiklopedia alat ukur fisika dapat digunakan sebagai sumber belajar untuk siswa SMP/MTs.

\section{DAFTAR PUSTAKA}

Akbar, S. 2013. Instrumen Perangkat Pembelajaran. Bandung: Remaja. Ansharullah, dkk. 2015. Pengembangan Ensiklopedi Elektronika Berbasis Wiki. Jurnal Teknik Elektro, 7(2), 7175.

Busljeta, R. R. 2013. Effective Use of Teching and Learning Resources. Czech-Polish Historical and Pedagogical Journal, 5(2), 55-69.

Devy, R. 2015. Pengembangan Ensiklopedia Brainware of Chemistry Tokoh Kimia di Buku Kelas X SMA/MA sebagai Sumber Pengetahuan dan Pendidikan Karakter Bagi Siswa. Skripsi. Yogyakarta: Universitas Negeri Yogyakarta. Driscoll, M. P., et al. 1994. How does the textbook contribute to learning in a middle school science class? Contemporary Educational Psychology, 19, 79100.

Dwiyogo, W. D. 2016. Pembelajaran Visioner. Jakarta: PT. Bumi Aksara.

Fitriyani, D. 2017. Pengembangan Perangkat Pembelajaran IPA untuk

Meningkatkan Kemampuan Berpikir Tingkat Tinggi dan Penalaran Ilmiah Siswa Sekolah Menengah
Pertama. Jurnal Pembelajaran Sains, 1(1).

Hatibe, A. 2012. Metodologi Penelitian Pendidikan Ilmu Pengetahuan Alam. Yogyakarta: SUKA-Press UIN Sunan Kalijaga.

Irawati, I. 2015. Pengembangan Ensiklopedi Keanekaragaman Tumbuhan Angiospermae Berbasis Potensi Lokal di MTs Negri Seyegan Dengan Muatan Keislaman. Skripsi. Yogyakarta: UIN Sunan Kalijaga.

Kurniawati, D. 2018. Mengenal Laboratorium Sekolah. Surakarta: PT. Aksara Sinergi Media.

Nasution, S. W. R. 2019. Pengaruh Penguasaan Pengukuran Terhadap Hasil Belajar Fisika Siswa pada Materi Besaran dan Satuan. Jurnal Education and Development, 7(4), 175-179.

Noviar, D. 2015. Pengembangan Ensiklopedi IPA Terpadu Berbasis Scientific Approach dan Indigenous Science untuk Siswa Kelas VI SD/MI dalam Rangka Implementasi Kurikulum 2013. ALBIDAYAH: Jurnal Pendidikan Dasar Islam, 7(2), 125-134.

Nurhatmi, dkk. 2015. Pengembangan Ensiklopedia Digital Teknologi Listrik Berbasis Contextual Teaching and Learning (CTL). Edu-Sains, $4(1), 37-42$.

Prasetyowati, R. 2014. Pembelajaran IPA SMP Menurut Kurikulum 2013. Makalah. Disampaikan pada kegiatan PPM tentang "Pelatihan Penyusunan Model Instrumen 
Penilaian dan Penskorannya pada Pembejaran IPA Menurut Kurikulum 2013 bagi Guru IPA di Kecamatan Danurejan" tanggal 31 Oktober 2014.

Rohmawati, L., dkk. 2015. Pelatihan Penggunaan Alat Ukur dan Pengukuran bagi Guru IPA SMP Wilayah Sidoarjo. Jurnal ABDI, 1(1), 18-24.

Sari, I. N., \& Saputri, D. F. 2016. Analisis Kesalahan Menggunakan Alat Ukur pada Mahasiswa Program Studi Pendidikan Fisika IKIP PGRI Pontianak. Jurnal Edukasi, 14(2), 237-248.

Setiadi, A. E., \& Setiawati, E. 2016. Pengembangan Ensiklopedia Keanekaragaman Hewan Vertebrata Berbasis Spesimen. Jurnal Ilmiah Biologi "Bioscientist," 4(1).

Sulistiyawati, \& Hedianti, R. 2015. Pengembangan Ensiklopedia Peralatan Laboratorium Biologi Sebagai Sumber Belajar IPA Biologi untuk Siswa Kelas VII SMP/MTs. Seminar Nasional XII Pendidikan Biologi FKIP Tahun 2015. Surakarta: Universitas Negeri Sepuluh November.
Supriyadi, \& Lismawati, I. 2018. Pra Praktikum: Pengembangan Ensiklopedia Alat-alat Laboratorium Biologi Di SMP/MTs. Journal of Biology Education, 1(1), 81-92.

Ula, S. et. al. 2018. The Analysis of Efectiveness of Labiratory Use Toward Physic Learning Result at Senior High School in Banda Aceh. UNNES Science Education Journal, 7(2).

Vannesa, G. 2013. Pembuatan Ensiklopedia Hewan Punah Dan Terancam Punah Berbasis Web. Caliptra: Jurnal Ilmiah Mahasiswa Universitas Surabaya, 2(1-6).

Varma, K. 2014. Supporting scientific experimentation and reasoning in young elementary schoostudents. Journal of Science Education and Technology, 23(3), 381-397.

Widiana, A. P., \& Hasanah, D. 2014. Pengembangan Ensiklopedia Alat Ukur Fisika Sebagai Sumber Belajar Mandiri untuk Sma/Ma Kelas X pada Materi Besaran dan Satuan. Jurnal Ilmiah Pendidikan Fisika, 4. 
Phy. Educ. Res. J. Vol. 3 No. 1 (2021), 53-64 